Information about the authors: Elena Nikolaevna Klemenova - Doctor of Philological Sciences, Professor, Department of Journalism, Rostov State University of Economics (RINE),

Russia, Rostov on Don

klemenova@yandex.ru

Nadezhda Vladimirovna Kovalchuk - PhD, Associate Professor, Department of Foreign Languages, Don State Technical

University, Russia, Rostov on Don

nadezhda_kovalchuk_2012@mail.ru

Информация об авторах:Елена Николаевна Клеменова -доктор филологических наук, профессор кафедры

журналистики, Ростовский государственный университет экономики Ростов-на Дону, Россия

klemenova@yandex.ru

Надежда Владимировна Ковальчук - кандидат филологических наук, доцент кафедры иностранных языков, Донской государственный технический университет

nadezhda_kovalchuk_2012@mail.ru

Manuscript received: 05/10/2019 Accepted for publication: 09/20/2019

DOI:

\title{
LANGUAGE NORMS AND USAGE IN UKRAINIAN MASS MEDIA
}

\author{
Svitlana Korotkova \\ PhD, Associate Professor \\ National Technical University "Dniprovska Polytechnica" \\ (Dnepr, Ukraine) \\ e-mail: sveta_korotkova@i.ua \\ Olena Polovynko \\ PhD, Associate Professor \\ University of Strasbourg \\ (Strasbourg, France) \\ e-mail: polovynko@unistra.fr
}

\begin{abstract}
This research traces the evolution of the norms of the Ukrainian and Russian languagesand their usage in modern Ukrainian media discourse. In linguistic literature widespread understanding of the norm (tradition of the use of linguistic units) and narrow (result of purposeful language codification)are extended. The process of standardization of Ukrainian and Russian languages took place in different ways. The national Ukrainian literary language belongs to the languages with an ancient tradition but its norms were not established until quite recently, having changed several times. Analysis of media discourse reveals that a high level of proficiency in the state language demonstrates a limited group of the country's population. As for the Russian language, while it does not lose its communicative power in many regions of Ukraine, in the speech of monolinguist Russophones there are errors and ukrainisms.The intermediate Ukrainian-Russian language varieties, surzhyk,holds a special position in the media and public performances. In general, the contemporary Ukrainian media discourse demonstrates non-compliance with legislative and academic requirementsbut reflects the complexity of the linguistic situation in Ukraine.
\end{abstract}

Keywords: language norm, language standardization (normalization), media discourse, Ukrainian language, Russian language, surzhyk

НОРМЫ И ФУНКЦИОНИРОВАНИЕ ЯЗЫКОВ В УКРАИНСКИХ МАСС-МЕДИА

\author{
Светлана Витальевна Короткова \\ Кандидат филологических наук, доцент \\ Национальный ТУ «Днепровская политехника», \\ (Днепр, Украина) \\ e-mail: sveta_korotkova@,i.ua
}

Елена Алексеевна Половинко

Кандидат филологических наук, ассоциированный профессор

Страсбургский университет,

(Страсбург, Франция)

e-mail: polovynko@unistra.fr

Аннотация: В данном исследованииособое внимание уделено истории становления норм украинского и русского языков и функционированиюязыковых систем в современном украинском медиадискурсе. В лингвистической литературе встречается 
как широкое понимание нормы (традиции употребления языковых единиц), так и узкое (результат целенаправленной кодификации языка). Процессы стандартизации украинского и русского языков протекали по-разному. Украинский литературный язык относится к языкам с древней традицией, однако его нормы изменялись неоднократно и установились формально не так давно. Анализ украинского медийного дискурса показывает, что высокий уровень владения государственным языком демонстрируетне всё население страны. Что касается русского языка, он не теряет своей коммуникативной мощности в отдельных регионах Украины, однакоречьрусофоновне лишена ошибок и украинизмов. Особое положение в средствах массовой информации и публичных выступлениях занимает смешанная украинско-русская речь, суржик. В целом приходится констатироватьналичие некоторых несоответствий современного украинскогомедиадискурсазаконодательным и академическим требованиям. Неоспоримой при этом остается важность изучения данной сферы функционирования языков для описания языковой ситуации в Украине.

Ключевые слова: языковая норма, стандартизация (кодификация) языка, медиадискурс, украинский язык, русский язык, суржик.

INTRODUCTION. Nowadays, when high technologies have penetrated deeply into our lives, it is difficult to imagine that just over one century ago TV did not even exist. In the Soviet Union, TV translation was born in the first half of the last century: the first experimental picture's transmissions were realized in 1931 by the laboratory of television in AllUnion Electrotechnical Institute in Moscow. The first images were motionless- pictures of famous artists and honored workers of the country. On the $1^{\text {st }}$ of October, a statementappearedin the newspapers that for the first time in the USSR, a regular broadcasting of "moving images" would begin. "Comradesradioviewers, said the speakers, we are starting transmission of the Soviet farvision'. The word 'televiewer' and the notion of 'television' have not entered into use... ${ }^{18}$. In 1967, regular color broadcasting began in the $\mathrm{USSR}^{19}$.

In the Soviet era, television speakers demonstrated the highest mastery of speech and television was a reliable source of language knowledge. However, the Ukrainian sociolinguists foundanother role of the Soviet television: with the advent of television, according to LaryssaMasenko, the Soviet government received a powerful tool of russification, which, along with the radio, gave it the opportunity to strengthen and accelerate the processes of linguistic and cultural unification of the peoples of the USSR (Masenko 2013: 83).

In independent Ukraine, state language policy, especially in recent years, has been aimed at popularizing the only state language - Ukrainian, but Russian speech is still heard from TV screens; moreover, the interpretationof the language norms of these languages is sometimes very blurred. Ukrainian literary language, firstly, has not yet acquired a stable norm, as evidenced by its variation on different TV channels, and secondly, a high level of proficiency in the state language demonstrates a limited group of the country's population. As for the Russian language, while it does not lose its communicative power in many regions of Ukraine, in the speech of monolinguist Russophones there are errors and "ukrainisms".

The purpose of this research is to trace the evolution of the norms of Ukrainian and Russian languages, as well as to analyze their use on the air on the five highest rated TV channels of Ukraine(according to the rating published in November 2018 on the website of the National Council of Ukraine on television and radio broadcasting ${ }^{20}$ ) in order to establish the degree of compliance of the modern Ukrainian media discourse within the legislative and academic requirements. The special position of surzhyk, intermediate Ukrainian-Russian language varieties, in the media and public presentations is being examined.

THEORETICAL BASIS. The term "norm" has the need to be specified because itremains a source of many ambiguities. In a broad sense, the norm is close to the concept of usus - the generally accepted way of using the language. This way of speech has developedspontaneously andbecome a traditionand it alsodistinguishesonelanguage idiom from other language idioms. In a narrow sense, the norm is inextricably linked to the concept of literary (normalized or codified) language as the result of purposeful language codification (Itskovich 1970: 9). Eugen Coseriu was one of the first in language science who put forward a dual understanding of the norm: descriptive(reflecting the tradition) and prescriptive (reflecting the requirement) (Coseriu 1963: 175). The concept of "norm" and the concept of "codification" weredefinedspecifically in the works of BoguslavHavranek, who stressed the need to distinguish between the validity of the norm, its real state and the idea of it, materialized in the dictionaries and reference literature (Havranek 1967).

The sociolinguists prefer to talk about the distinction between norm as language productions "as it should be" and variability as productions as they really are, but also about the distinction between spoken and written language: the norm is related to writing, the variation, on the other hand, is mainly seenand evident in the oral language, even if it seems that an important activity of the speaker is to try not to perceive it (Gadet 1995: 20). The oral form is characteristic ofdirect communication between people, it is more mobile, characterized primarily by features in the syntax and vocabulary. The written form of functioning differs from the oral form by the strictest selection of words, the representation of exact constructions, the use of a significant amount of abstract vocabulary.

Despite the fact that both Ukrainian and Russian represent a single group of Eastern Slavic languages and began to form as separate linguistic systems at the same time, the process of their normalization took place in different ways.

\footnotetext{
${ }^{18}$ Translated into English by O. Polovynko from: «Товарищи радиозрители, - говорили дикторы, - начинаем передачи советского дальновидения...». Слово «телезритель» и понятие «телевидение» еще не вошли 6 обиход...(https://tass.ru/spravochnaya-informaciya/523158 [10.02.2019]).

${ }^{19} \mathrm{https}: / /$ ria.ru/20121001/761256162.html [10.02.2019].

20 https://www.nrada.gov.ua/reityngy-telekanaliv-sered-korystuvachiv-iptv-ott-u-ii-kvartali-2018-roku/[15.02.2019].
} 
HISTORICAL CONTEXTE. Traditionally, the Russian literary language of the great Russian nation of the Moscow state dates from the late XIV - mid XVII century (Erofeeva 2014: 18). The XVIII century was the period oftransformation and enrichment, as the religious roots of the written form and the popular variants of the spoken form combined in a single language. VasilyTrediakovsky was the first who gave a theoretical substantiation of the necessity of the regulation ofthe Russian literary language. However, the reformatory activity of Mikhail Lomonosov, who developed the "theory of three styles", acquired special significance for the normalization of the language.It was the first step to the modern literary Russian.Otherimportant contributions to the process of standardizing weremade by Nikolay Karamzin, Aleksander Pushkin, Ivan Turgenev, Nikolay Gogol, and Fyodor Dostoevsky. The nineteenth century witnessed the establishment of standard Russian and the period of its greatest thriving. Modern Russian literary language is the language that has existed from Pushkin to the present day.

Ukrainian had, for a longer time,only a popular, spoken form. Ivan Kotliarevsky used this popular, folkloric material to create his literary style, thereby founding a new literary language, in the very end of eighteenth century. Another great Ukrainian poet, Taras Shevchenko, perfected Ukrainian, and contributed to its lexical and stylistic enrichment in terms of synonymy, neology, rhythm, and so on. His name has come to represent not just literature, but Ukrainian culture as a whole. Shevchenko was followed by a host of writers such asPanteleimonKulish, LesyaUkrainka, Ivan Franko, MykhailoKotsiubynsky, each of whom helped Ukrainian flourish (Shevchenko 2015). However, the control of Ukrainian territories by two different empires determined different conditions for the subsequent development of the title language of the Ukrainian nation. East Ukrainian and West Ukrainian variants of the literary language in the second half of the nineteenth century developed in isolation, based on different dialects.

The russification of a large part of Ukraine, which was controlledby the Russian Empire, led to the prohibition of Ukrainian in school and relegation to the status of language of rural register. In Galicia, the western part under Austrian tutelage, the development of the Ukrainian language was relatively free; the question of the canons of a standard Ukrainian language was raised and a chair of Ukrainian philology was created in 1849.

The USSR developed the use of Ukrainian starting in the $1920 \mathrm{~s}$, but by choosing a variant of central Ukraine, closer to Russian than the one that had been codified in Galicia (Marchand, $2014: 3$ ). The existence of two variants of the Ukrainian literary language in the XIX century in Soviet linguistics was ignored.The Bolsheviks, in the fight against illiteracy, opened more than eighteen thousand Ukrainian schools (Romancov,2008: 11) however, this policy was reversed in the middle of 1930s by a growing russification (Seriot $2005: 41$ ) which led to bilingualism in favor of the Russian language.

Thus, the Ukrainian national literary language belongs to the languages with an ancient tradition but its norms have been established quite recently, having changed several times. It is inherent in some "artificiality, immobility of norms" (Vydajchuk 2015: 199). Historical and socio-political factors limited its opportunities for functioning in all spheres of lifeand natural development. At the time of Ukrainianindependencethere is a tendency to focus on a more multifunctional Western Ukrainian version of the literary Ukrainian language. This tendency in particular began to spread in some media.

CURRENT LAGISLATIVE FRAMWORK. The information sphere of a democratic society presupposes the functioning within its framework of the media space as a communicator-intermediary between the source of information and the person (citizen) who wants to receive this information (Malyk 2009: 122). Television along with the press, radio and Internet sources provides information to the consumer. At the same time, the mass media discourse, in particular television broadcasting, reflects the communicative power of language systems operating in the territory of the state and providescontentfor the study of the linguistic situation.

The materialtaken from the television news releases of the five most popular Ukrainian TV channels, demonstrates the presence of several language systems in the Ukrainian mass media discourse and tracksthe results of innovative processes in the languages (lexical and semantic neologisms, "reanimated" archaisms, periphrases, idiomatic expressions, adoptions from other languages).

Media space as part of the general information space of Ukraine is clearly regulated by national legislation. Thus, the Law of Ukraine "On television and radio broadcasting" determines the volume of broadcasting that should be carried out in the state language: "In the total weekly volume of TV and radio broadcasting... programs and/or films made in the state language must be at least 75 percent of the total duration of programs and/or films (or parts thereof) in each period between 07.00 and 18.00 and between 18.00 and $22.00^{, 21}$. According to the Constitution of this state, the only official language is Ukrainian. However, the following paragraphs of this article leave much more space for other communication systems: the live broadcast program is considered to be made in the state language, if the speech (replicas) of the presenters (announcers) of the TV program is in Ukrainian. Television news releases remain a type of program which is allowed to use other languages without dubbing or subtitles "in the direct reportage from the place of incident (except for the discourse and replicas of reporters) in speeches, interviews, comments, explanations, questions, etc. of persons who participate in the program (except for the presenters) in volume, determined by the concept of the program, 22 . And this does not contradict either the Constitution which guarantees the free development, use and

\footnotetext{
21 Translated into English by O. Polovynko from: У загальному тижневому обсязі мовлення телерадіоорганізацій... передачі та/або фільми, виконані державною мовою, мають становити не мение 75 відсотків загальної тривалості передач та/або фільмів (або $\ddot{i x}$ частин) $y \quad$ кожному проміжку часу між $07.00 \quad$ та $18.00 \quad i \quad$ між $18.00 \quad$ та 22.00(https://zakon.rada.gov.ua/laws/show/3759-12[28.02.2019]).

${ }^{22}$ Translated into English by O. Polovynko from: $У$ репортажі з місия події (крім мови та реплік репортерів) у виступах, інтерв'ю, коментарях, поясненнях, запитаннях тощо осіб, які беруть участь у передачі (крім ведучих (дикторів) передачі),
} 
protection of the Russian language and other languages of the National Minorities of Ukraine, or the actual linguistic situation of the country where only half of the population considers Ukrainian as their unique mother tongue and only a quarter invest as monolingual Ukrainians (Polovynko 2018: 287).

DATA ANALYSIS. The announcers of TV programs and journalists belong to the category of people who is obliged to be fluent in the state language in order to ensure one of the most important requirements for television and radio broadcasting - improving the educational and cultural level of citizens. It should be recognized that the Ukrainian news presenters and reporters of all five channels which came into our field of research (1+1, Ukraina, STB, ICTV, Inter) demonstrate a high level of knowledge of the Ukrainian literary (codified) language. At the same time, a few tendencies are noticeable, especially in the speech of the announcers of the leading channel in this rating: 1 . Preference is given to a vocabulary that is different from the Russian equivalents(holovnoinstead of holovnymchynom [mainly], kredens instead of buffet dliaposudu[cupboard for dishes], papliuzhyty, han'bytyinstead ofzasudzhuvaty, porochyty[todefame]). 2. Word-building models, typical for the Ukrainian are attracting more motivating bases. This is illustrated, for example, by the processes of feminization of names of persons by occupation: vykonuvachka [executant, f], ministerka [Minister, f], pedagogynia [pedagogue, f] and even names of animals: babachykha [marmot, f], hryzunka [rodent, f]. On the model of neuter nouns ending in -ння (obhovorennia [discussion]) the new ones are created: nastoluvannia [enthronement]. 3. The formation of adjectives with evaluative suffixes ( $n$ 'янезний[very drunk]), including the forms of the comparative degree from the relative adjectives and derivative adverbs (vesnianiche [more like in spring]).

All this does not detract the professionalism of the Ukrainian news presenters and journalists, but indicates that the Ukrainian language develops naturally, like any language system. However, in the news we hear more than just the speech of professional presenters. Informative programs cover events in all possible areas of public life, and in the presentations of reporters there are comments of participants of the relevant events, witnesses, experts representing different social strata of the population, a variety of fields of public life, all with different levels of education. While announcers and journalists are required to master perfectly the state language another participant of this program could represent any of the linguistic groups present in Ukraine, and speak in a language in which it is more comfortable for him to communicate. Furthermore, the replicas in Russian on live air are usually not dubbed.

The monitoring of news releases on the five Ukrainian TV channels studied revealed the geography of linguistic groups. The population of Ukraine is made up of a plurality of communities spread over several linguistic regions: a predominantly Ukrainian-speaking western part, a predominantly Russian-speaking eastern part and the intermediate regions where not only Ukrainian and Russian compete but also a mixture of these languages, surzhyk, is widespread. However, internal migration flows, which have intensified in recent years due to the military conflict in Eastern Ukraine, blurs the borders of these regions.

The geographical factor often beatsthe social one: even some civil servants, teachers, and doctors prefer to answer in Russian to the question that the journalist asks in Ukrainian. Furthermore,both Ukrainian and Russian speech are saturated with phonetic, lexical and grammatical interferences:1. At the phonetic level we can observe in Russian speech the distinction of the pronunciation of the vowel phonemes /a / and / $\mathrm{o} /$ in the non-accented syllables, which is representative of a phonetic feature of the Ukrainian language; and the non-distinction of the phonemes mentioned in the same positionsin Ukrainian speech instead, which is characteristic of the literary Russian language. 2. Influence of the Russian literary language appears in the consonantism system, in particular, there is devocalization of voiced consonants in a weak position in Ukrainian words.3. Vocabulary is another level where interaction of Russian and Ukrainian is shown as strongly as in phonetics. Ukrainophones use Russian words (skryvatyinstead of khovaty[to hide])or combine the words according to the Russian lexical compatibility (zadavatypytanniainstead of stavytypytannia[ask a question]).Russophone, in their turn, use the Ukrainianclichés which demonstrates the predominance of the Ukrainian language in the official sphere (vyborchyiprotsesinstead of izbiratel'nyjprotses[electoral process]).

The analysis of the Ukrainian television news, particularly of the texts that are broadcast in the context of such programs, leads to the conclusion that the specificity of the Ukrainian media discourse is not only the functioning of two languages, but also the presence of an intermediate system that is the result of constant contacts between these two languages : from the TV screen we can hear not only the russisms in the Ukrainian language and vice versa, but also a real surzhyk "a pejorative collective label for non-standard language varieties that dissolve the language boundary between the Ukrainian and Russian standard languages" (Bernsand, 2001: 38), a linguistic hybrid, extremely complex for exhaustive scientific analysis and clear typology. On one hand, there is a group of monolinguals for whom surzhyk is the only means of communication. Most of them are the residents of small cities and villages, as well as people originating from villages who have education not higher than secondary. On the other hand, elements of mixed Ukrainian-Russian speech can be consciously used by bilinguals (multilinguals) and becomes a certain stylistic device, a specific feature of the person as a symbol of a certain social type widely represented in the Ukrainian society. Both of these typesof surzhykophones can be regularly heard from the Ukrainian television.

Nonetheless, such defects are deemed acceptable by the Ukrainian National Council of television and broadcasting. Thus, one of the members of this state organ, SergiyKostynsky, said, commenting on the entry into force of the law on Ukrainian television quotas, that the discourse in surzhyk, in local dialect or russisms in Ukrainian speech

\footnotetext{
або в окремих репліках ведучих (дикторів) передачі в обсязі, обумовленому творчим задумом передачі (https://zakon.rada.gov.ua/laws/show/3759-12[28.02.2019]).
} 
will be taken into account in the quota on the Ukrainian language on television ${ }^{23}$. In this case, the language norm is perceived as part of social norms, which means that the prestige of a variety does not derive from its inherent qualities, but from its social value. In other words, the attempt to speak Ukrainian even without perfect knowledge of this language is valuable.

CONCLUSION. If we study only the speech of news presenters and journalists, the Ukrainian media discourse can be considered as a source of codifiedlanguage knowledge, illustration of language developmentand changes in public consciousness.As for the other participants of the relevant programs, we have to state that for a large part of the Ukrainian population the standard Ukrainian remains a difficult ideal to achieve and many either prefer to speak Russian or ignore the norms that delimit the two languages.

On April 25, 2019, the Ukrainian Parliament adopted a new law on the state language - "On ensuring the functioning of the Ukrainian as the state language." This lowwill regulate more than 30 different areas of public life. In particular, the law will provide at least 90 percent of the Ukrainian language on national TV channels; at least 50 percent of the names of Newspapers and magazines in the Ukrainian language at distribution points; at least $50 \%$ of the names of Ukrainian-language books in the bookstores and publishers; the Ukrainian version of the authority sites, online stores and media. The law provides the clear mechanisms to monitor its implementation ${ }^{24}$.

The presentstudy can serve as a material for comparison with the results of a similar analysis a few years later after the entry into force of this new law.

\section{LIST OF REFERENCES}

Bernsand N. (2001). Surzhyk and National Identity in Ukrainian Nationalist Language Ideology. Berliner Osteuropa Info,38-47. Coseriu E. (1963), Sinkhroniya, diakhroniya i istoriya [Synchrony, diachrony and history]. Novoe v lingvistike[New in linguistics]. 3. 143-343.

Erofeeva I. V. (2014). Istoriya russkogo literaturnogo yazyka [The history of Russian literary language]. Kazan.

Gadet F. (1995), Norme, variation, évaluation. Histoire. Épistémologie. Langage. 1995, 11, 18-22.

Havranek B. (1967), Zadachi literaturnogo yazyka $i$ ego kultura [Purposes of literary language and its culture]Prazhskijlingvisticheskijkruzhok [Prague linguistic circle]. Moscow. 338-377.

Itskovich V. A. (1970). Normaiee kodifikatsiya [Norm and its codification]. Aktual'nye problemy kul'tury rechi[Actual problems of speech culture]. Moscow: Nauka,9-40.

Malyk I. (2009), Natsional'nyj media-prostir v umovakh hlobalizatsiy: pryyomy borot'by ta pravyla zakhystu [National media space in the context of globalization: methods of struggleand rules of protection]. Ukrayins'ka natsional'na ideya: realiyi ta perspektyvy rozvytku [Ukrainannationalidea: realitiesandprospectsofdevelopment]. 21. 122-127.

Marchand P. (2014), Le conflit ukrainien, des enjeux géopolitiques et géo économiques, Echo Géo. http://journals.openedition.org/echogeo/13976 [20.10.2018].

Masenko L. T. (2013), Manipuliatyvni stratehii dyskryminatsii ukrains'koi movy na telebachenni radianskoi I postradianskoi Ukrainy [Manipulative strategies of discrimination of the Ukrainian language on television of Soviet and post-Soviet Ukraine]. Movoznavstvo [Lingvistics]. 5. 83-88.

Polovynko O. (2018), Langue maternelle vs. identité linguistique et nationale : les standards ukrainiens et les Ukrainiens hors standard.Alén Garabato C., Boyer H., Djordjevic Léonard K. et Pivot B. (éd.), Identités, conflits et interventions sociolinguistiques.Limoges: Lambert-Lucas, 283-291.

Romantsov V. (2008), Naselennia Ukrainyi yoho ridna mova zachasiv radianskoi vlady ta nezalezhnosti (KhKh - pochatok KhKhIstolittia)[Population of Ukraine and its native languageduring Soviet power and independence (XX - beginning of XXI century)], Kyiv : Olena Teliga.

Sériot P. (2005), Diglossie, bilinguisme ou mélange de langues : le cas du suržyk en Ukraine. La linguistique. 2, vol. 41. Presse Universitaire de France. 37-52.

Shevchenko N. (2015), The history of bilingualism in Ukraine and its role in today's political crisis.https://www.cairnint.info/load pdf.php?ID_ARTICLE=E_CSP 017 0203[19.02.2019].

Vydajchuk T. L. (2015), Do problem dialektnoi osnovy ukrainskoi literaturnoi movy [On the problem of dialect basis of Ukrainian literary language]. Naukovyi chasopys Natsional'noho pedahohichnoho universytetuimeni M. P. Drahomanova. Seriia 10: Problemy hramatyky I leksykolohii ukrains'koi movy [Scientific journal of the National Pedagogical Dragomanov University. Series 10: Problems of grammar and lexicology of the Ukrainian language]. Kyiv. 12. 199-204.

\section{For citation:}

Korotkova Svitlana \& Polovynko Olena (2019) LANGUAGE NORMS AND USAGE IN UKRAINIAN MASS MEDIA // International Scientific-Pedagogical Organization of Philologists “WEST-EAST” (ISPOP). Scientific Journal WEST-EAST. Vol 2/1 N1 (October, 2019). pp. 80-85. doi:

\section{Для цитирования:}

Короткова С. В., Половинко Е.А.(2019) НОРМЫ И ФУНКЦИОНИРОВАНИЕ ЯЗЫКОВ В УКРАИНСКИХ МАСС-МЕДИА // Internationa 1Scientific-Pedagogical Organization of Philologists “WEST-EAST” (ISPOP) . Scientific Journal WEST-EAST. Vol 1/1 N1 (October, 2019). C.80-85. doi:

\section{Information about the authors:}

Svitlana Korotkova - PhD, Associate Professor at National Technical University "DniprovskaPolytechnica”, Ukraine e-mail: sveta korotkova@i.ua

\footnotetext{
${ }^{23}$ https://prm.ua/rusizmi-dialekti-ta-surzhik-u-teleefiri-bude-zarahovano-ukrayinomovnoyi-kvotinatsteleradio/[11.03.2019].

${ }^{24}$ http://language-policy.info[26.04.2019].
} 
Olena Polovynko - PhD, Associate Professor, Research and Teaching Associate at the University of Strasbourg, France e-mail: polovynko@unistra.fr

Сведения об авторах: Светлана Витальевна Короткова - кандидат филологических наук, доцент, Национальный ТУ «Днепровская политехника», Днепр Украина

e-mail: sveta korotkova@i.ua

Елена Алексеевна Половинко - кандидат филологических наук, ассоциированный профессор, Страсбургский университет, Страсбург Франция

e-mail: polovynko@,unistra.fr

Manuscript received: 05/02/2019 Accepted for publication: 09/20/2019

DOI:

\title{
REGULARITY OF NATIVIZATION OF EXOTICISMS: LOANWORDS FROM THE SOUTH-ASIAN LANGUAGES IN THE CURRENT ENGLISH PRESS
}

\author{
Marina Kuzina \\ Candidate of Philology, Associate Professor \\ Moscow Pedagogical State University \\ (Moscow, Russian Federation) \\ e-mail: kouzina-marina@yandex.ru
}

\begin{abstract}
Conveying the foreign, alien background in poetry, plays, short stories and novels has traditionally been regarded as the major aim of resorting to exotic vocabulary in belles-lettres. In the present article the statistics are presented to highlight the regular usage of South Asian exoticisms in a wider range of the English functional styles. The functional assimilation of the analyzed lexical loanwords is revealed through comparing dictionary entries (to denote the retaining or loss of the culturally loaded component of the meaning) and their actual usage in the British and American newspapers ("The Guardian", "The Independent", "USA Today", "Washington Post"). The analysis of the current usage of exotic loanwords of South Asian origin contributes to the understanding of the conditions for the de-exoticization, i.e. nativization of exotic vocabulary. Among these the following features can be named: belonging to the groups of adjectives or verbs; relatively high level of the abstract meanings of the exotic nouns; the frequent occurrence in contemporary written journalese style; the topical socio-cultural context of its usage.
\end{abstract}

Keywords: South Asian loanwords; exotic word/exoticism; de-exotization; culture-loaded meaning

\section{ЗАКОНОМЕРНОСТИ ПРОЦЕССА ДЕЭКЗОТИЗАЦИИ (НА ПРИМЕРЕ ФУНКЦИОНИРОВАНИЯ ЗАИМСТВОВАНИЙ ИЗ ЯЗЫКОВ ЮЖНОЙ АЗИИ В СОВРЕМЕННОЙ АНГЛОЯЗЫЧНОЙ ПРЕССЕ)}

\author{
Марина Кузина \\ Кандидат филологических наук, доцент \\ Московский педагогический государственный университет \\ (Москва, Российская Федерация) \\ e-mail: kouzina-marina@yandex.ru
}

\begin{abstract}
Аннотация. Создание образа инонациональной речевой среды в художественной литературе традиционно рассматривается как основная цель употребления экзотической лексики в данном функциональном стиле. В данной статье приводятся статистические данные, свидетельствующие об активном употреблении ряда заимствований из языков Южной Азии в более широком диапазоне функциональных стилей современного английского языка. Особенности протекания процесса деэкзотизации устанавливаются путём анализа этимолого-культурологических помет в вокабулах с экзотизмом в качестве заголовочного слова, а также посредством привлечения контекстов их фактического употребления на страницах британских и американских периодических изданий («The Guardian», «The Independent», «USA Today», «Washington Post»). Изучение употребления южно-азиатских экзотизмов в современных англоязычных периодических изданиях позволяет сделать выводы об условиях утраты ими национально-культурной составляющей семантики: отнесение к классам имен прилагательных или глаголов, достаточно высокий уровень абстрактности у имён существительных, актуальный социокультурный контекст употребления и высокая частотность употребления.
\end{abstract}

Ключевые слова: заимствования из языков Южной Азии; экзотизм; деэкзотизация; национально-культурный компонент значения 